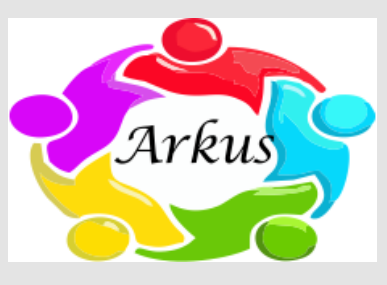

\title{
ARKUS
}

Journal Homepage:

https://hmpublisher.com/index.php/arkus

\section{Increasing Public Knowledge About Covid-19 Prevention through the Implementation of Health Protocol and Self Medication}

\section{Nita Parisa ${ }^{*}$, Evi Lusiana ${ }^{1}$, Nia Savitri Tamzil ${ }^{1}$}

${ }_{1}^{1}$ Department of Pharmacology, Faculty of Medicine, Universitas Sriwijaya, Palembang, Indonesia

\section{A R T I C L E I N F O \\ Keywords: \\ Covid-19 \\ Self-Medication \\ Community \\ Corresponding author: \\ Nita Parisa \\ E-mail address: \\ nitaparisa@unsri.ac.id}

All authors have reviewed and approved the final version of the manuscript.

https://doi.org/10.37275/arkus.v6i1.81

\begin{abstract}
A B S T R A C T
Covid-19 is a disease caused by the SARS Cov-2 virus and attacks the respiratory tract. This disease spreads very quickly through droplets. Until now, there is no definitive therapy for this disease. However, prevention that can be done to prevent this disease are implementing health protocols, social distancing, increasing endurance by consuming nutritious foods, exercising and regular rest, stress management, and self-medication.
\end{abstract}

\section{Introduction}

Covid-19 is a disease caused by the SAR-Cov-2 virus and most often attacks the respiratory tract. This disease is widespread. This virus spreads through the air (Airborne Disease) by splashing liquid from the human respiratory tract (droplets) that can come out when we cough, sneeze and even talk.1,2

The spread of the corona virus can be controlled in the following ways such as wearing a mask when sick and healthy, washing hands frequently with water and soap for 20 seconds or using an alcoholbased or herbal handsanitizer, keeping a distance from other people and avoiding crowds like schools, markets, restaurants, hospitals, and other public facilities, then maintaining mental and physical health with consume foods with balanced nutrition, regular exercise, enough rest, take vitamins if necessary (self-medication) and be wise in receiving information about Covid-19.3,4

The Covid-19 Pandemic period forced us to or not, like it or not, must apply health protocols and carry out social distancing. Although, this health and social distancing protocol has been promoted by the government, in practice there are still many people who do not understand so they are negligent in implementing it. Moreover, efforts to prevent Covid19 still raise questions in the community, from vaccines to supplements that should be consumed. 
Based on the various problems faced, it is important to do community service for increasing public knowledge and understanding of the importance of health and social distancing protocols, independent and self-medicated health screening and the role of supplements using vitamins and herbs in efforts to prevent Covid-19. it is hoped that the number of Covid-19 cases in Palembang City will be reduced.

\section{Methods}

The community service was conducted by the lecturer of Department of Pharmacology and undergraduate students of Faculty of Medicine, Universitas Sriwijaya. It was held in the end of the year 2020 using the online media application Zoom Meeting. The target of activities includes the people of Palembang City. Activities carried out in the form of comprehensive health education including pharmacological aspects to the community. Evaluation of activities will be carried out by direct observation of participants, discussions, and questions.

\section{Results and Discussion}

Palembang is one of the big cities with a relative high number of confirmed Covid-19 cases. The number of confirmed cases in December 1, 2020 are 2238 people. $^{5}$ Although in November 2020 the confirmed cases of Covid-19 in Palembang city began to decline, the risk of transmission still exists because Palembang is still included in the Orange Zone for the spread of Covid-19.6

In connection with the above, the community must remain obedient and adhere to health protocols and implement social distancing in their daily lives. One of the preventive efforts that can also be done to prevent the disease and spread of Covid-19 is done through increasing public awareness and knowledge about self-medication.
Self-medication is defined as the selection and use of medicines by individuals, which can be in the form of conventional medicines and herbal/traditional medicines that are used to treat diseases or symptoms that can be recognized on their own. ${ }^{7}$ With increasing public knowledge about self-medication, people can choose and use wisely the medicines they use for both therapy and prevention of disease. Of course, self-medication is limited to mild disease and not life-threatening. The more people do selfmedication for minor diseases or chronic disease with routine drugs, the accumulation of patients in hospitals can be avoided.

In this community service, health education is carried out to the public as a whole starting from an explanation of what Covid-19 is, how it spreads, how to prevent it, and efforts that can be made to prevent Covid-19. In addition, this activity also describes the importance of public knowledge about selfmedication so that people can increase endurance and overcome minor ailments independently using conventional and herbal medicines. The result of this activity is a decrease in the number of cases and the spread of Covid-19 with an increase in the knowledge of the people of Palembang city about health and selfmedication.

\section{Conclusion}

Nowadays, there is no definitive therapy for Covid19 , the application of health protocols and social distancing in everyday life and increasing body resistance with self-medication in example are the effort that can be done in preventing the spread of Covid-19.

\section{References}

1. WHO.

2020.

Coronavirus. http: / /www.who.int/healthtopics / coronavirus\#tab=tab_1 
2. CDC. 2020. Coronavirus Disease. https:// www.cdc.gov/coronavirus/2019ncov/index.html

3. Kemenkes. 2020. Info Corona Virus. https:// covid19.kemkes.go.id/category/situasiinfeksi-emerging/info-coronavirus/\#.X5fTSGkxd-E

4. Kemenkes. 2020. Pedoman Pencegahan dan Pengendalian Coronavirus Disease 2019 (Covid-19).
5. Palembang Tanggap Covid. 2020. Data Statistik Covid-19. https://hallo.palembang.go.id/covid19/

6. KPCPEN. 2020. Satuan Tugas Penanganan Covid-19. https://covid19.go.id/

7. Galato D, et al. 2009. Responsible selfmedication: review of the process of pharmaceutical attendance. Brazilian Journal of Pharmaceutical Sciences. 2009; 45(4): 625-633. 